\title{
PENERAPAN TEKNOLOGI SEMANTIC WEB PADA ARTIKEL WIKIPEDIA INDONESIA
}

\author{
Irvan Wahyu Nurdian', Faisal Rahutomo², Imam Fahrur Rozi ${ }^{3}$ \\ Program Studi Teknik Informatika, Jurusan Teknologi Informasi \\ , Politeknik Negeri Malang \\ irvan.wn@gmail.com, ${ }^{2}$ faisal_rahutomo@polinema.ac.id, ${ }^{3}$ imam.rozi@gmail.com
}

\begin{abstract}
Abstrak
Wikipedia adalah sebuah situs yang berisi tentang artikel ensiklopedia dan referensi online tingkat dunia. Artikel yang terdapat pada Wikipedia saat ini total telah mencapai lebih dari 37 juta artikel dari 250 lebih bahasa berbeda.Untuk Wikipedia Indonesia telah mencapai 371.281 artikel.Dengan sekian banyaknya artikel-artikel tersebut, tentunya bukan perkara mudah melakukan pencarian dengan cepat dan tepat sesuai dengan yang diharapkan. Maka dari itu dibutuhkan suatu metode yang dapat memecahkan masalah tersebut, yaitu metode semantic web. Penelitian ini dimulai dengan merancang ontologi berdasarkan class-class dari hasil clustering artikel Wikipedia Indonesia serta dilengkapi dengan pendefinisian property-property dari masing-masing class. Dilanjutkan dengan perancangan query dengan bahasa SPARQL. Pencarian artikel pada aplikasi ini diuji dengan menggunakan 3 perhitungan untuk mengukur akurasi sistem, yakni Precision, Recall dan F-Score. Pada perhitungan Precision mendapatkan nilai rata-rata 1, Recall mendapatkan nilai rata-rata 0.53. Lalu pada perhitungan akhir akurasi sistem didapat nilai pada F-Score 0.6935 atau dengan persentase akurasi $69,35 \%$.
\end{abstract}

Kata kunci : Semantic Web, Ontologi, Wikipedia, $S P A R Q L$

\section{Pendahuluan}

Perkembangan teknologi internet saat ini, telah merubah cara kita mencari dan memperoleh informasi. Sekarang pencarian informasi sebagian besar beralih ke internet. Mulai dari pencarian halhal sepele sampai kepada keperluan studi literatur. Salah satu situs web yang populer menjadi rujukan yaitu Wikipedia.

Artikel yang terdapat pada Wikipedia saat ini total telah mencapai lebih dari 37 juta artikel dari 250 lebih bahasa berbeda. Untuk Wikipedia Indonesia telah mencapai 371.281 artikel. Dengan sekian banyaknya artikel-artikel tersebut, tentunya bukan perkara mudah melakukan pencarian dengan cepat dan tepat sesuai dengan yang diharapkan. Maka dari itu dibutuhkan suatu metode yang dapat memecahkan masalah tersebut, yaitu metode semantic web.

Untuk menampilkan informasi yang kaya dan relevan, sebuah mesin terlebih dahulu harus memahami tentang makna atau isi dari sebuah informasi. Hal inilah yang akan ditawarkan semantic web. Untuk mewujudkan itu maka diperlukan sebuah domain knowledge, yang dalam semantic web dikenal dengan istilah ontologi. Dalam ontologi, informasi akan saling terkait membentuk sebuah knowledge yang akan dimanfaatkan oleh mesin untuk menyajikan informasi yang kaya dan sesuai dengan yang pengguna cari.

Dari penjelasan di atas, maka pada penelitian ini penulis mengusulkan untuk merancang aplikasi pencarian berbasis teknologi semantic web pada artikel Wikipedia Indonesia menggunakan pendekatan ontologi. Diharapkan dengan penelitian ini akan mampu memudahkan pencarian informasi maupun informasi terkait pada artikel Wikipedia Indonesia.

\section{Semantic Web}

Secara umum Semantic Web dapat diartikan sebagai informasi dalam jumlah sangat besar di World Wide Web yang terhubung secara global dengan suatu cara tertentu dan dimengerti / dipahami oleh mesin, sehingga dapat diproses secara langsung oleh mesin menjadi knowledge untuk ditampilkan kepada user. Semantic Web pertama kali dicetuskan oleh Tim Berners-Lee, penemu World Wide Web. Sekarang, prinsip Semantic Web disebut-sebut akan muncul pada Web 3.0, generasi ketiga dari World Wide Web.

Dengan metode Semantic Web, data berbasis HTML dapat diubah menjadi format yang dapat dipahami oleh mesin, sehingga mesin dapat melakukan proses pengumpulan informasi dan memahami hubungan antara informasi. Web semantik mampu melakukan perubahan ini dengan 
bantuan XML (Extensible Markup Language) dan data language standards seperti $R D F$ (Resource Description Framework) dan OWL (Ontology Web Language), dua standarisasi dari W3C (World Wide Web Consortium).

\section{Ontologi}

Istilah ontologi sebenarnya berasal dari istilah filosofi "ontology" yang artinya sesuatu yang sesungguhnya ada dan bagaimana menggambarkannya. Dalam dunia komputer ontologi digunakan untuk menspesifikasikan suatu konseptualisasi. Dalam istilah lain ontologi dijelaskan sebagai suatu representasi dari domain pengetahuan tertentu yang berisi istilah-istilah dalam domain tersebut beserta hubungan antara istilah-istilah yang ada.

Terdapat beberapa tahapan yang dilakukan dalam pengembangan ontologi (Noy, 2000) yaitu :

1. Menentukan domain dan batasan ontologi

2. Mempertimbangkan penggunaan ontologi yang sudah ada.

3. Menentukan istilah penting dalam ontologi

4. Mendefinisikan class ontologi dan menyusun class dalam hirarki taksonomi (subclass - superclass).

5. Mendefinisikan slot atau properties dan menjabarkan nilai dari slot tersebut.

6. Mendefinisikan facets pada slots.

7. Membuat instances.

\section{RDF (Resource Description Framework)}

RDF(Resource Description Framework) merupakan bahasa yang digunakan untuk merepresentasikan metadata. RDF mendukung interoperabilitas antar aplikasi yang mempertukarkan informasi yang bersifat machineunderstandable di web. Semantic web terdiri dari data yang ditulis dalam bahasa yang dapat dimengerti oleh mesin, seperti RDF. $R D F$ menggunakan graf untuk merepresentasikan kumpulan pernyataan. Simpul dalam graf mewakili suatu entitas, dan tanda panah mewakili relasi antar entitas.

Ada tiga obyek tipe dalam model data RDF (Lasila dan Swick, 1999) :

a) Sumber Daya (Resource)

b) Properti (Property)

c) Pernyataan (Statement)

\section{SPAROL}

SPARQL merupakan bahasa query untuk $R D F / O W L$. SPARQL menyediakan fasilitas untuk mengekstrak informasi dalam bentuk $U R I$, blank node dan literal, mengekstrak subgraf $R D F$, dan membangun graf $R D F$ baru berdasar pada informasi dari graf yang di-query (Prud'hommeaux dan Seaborne, 2005). Query SPARQL didasarkan pada pencocokan pola graf (Karsanti, 2006). Pola graf yang paling sederhana adalah triple pattern yang mirip dengan $R D F$ triple, hanya saja pola pada query dimungkinkan pemberian nama diluar terminologi $R D F$ pada posisi subyek, predikat dan obyek.

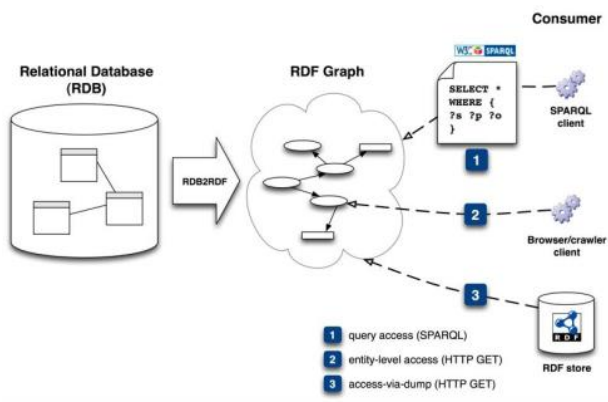

Gambar 1 : Gambaran umum SPARQL

\section{Perancangan Ontologi}

Perancangan ontologi untuk artikel Wikipedia Indonesia merupakan langkah awal dalam menentukan konsep dan domain yang akan dibangun. Noy dan McGuinness (2000) telah menjelaskan ada beberapa langkah-langkah yang harus diperhatikan.

1. Penentuan konsep dan domain

Domain dari penelitian ini adalah artikel Wikipedia Indonesia, yang diklasifikasikan menjadi beberapa class induk (superclass) dan subclass.

2. Mempertimbangkan ontologi yang sudah ada

Dalam pembuatan aplikasi ini, diasumsikan belum terdapat ontologi yang dapat digunakan untuk pengembangan sehingga dalam hal ini seluruh komponen dari ontologi dikembangkan dari awal.

3. Menentukan istilah penting dalam ontologi Dalam pembuatan ontologi pada aplikasi ini, menentukan istilah penting bertujuan untuk penamaan class

4. Mendefinisikan class ontologi dan menyusun class dalam hirarki taksonomi (subclass - superclass)

Rancangan class artikel Wikipedia Indonesia terdiri dari 10 class induk (superclass), yaitu sebagai berikut : 


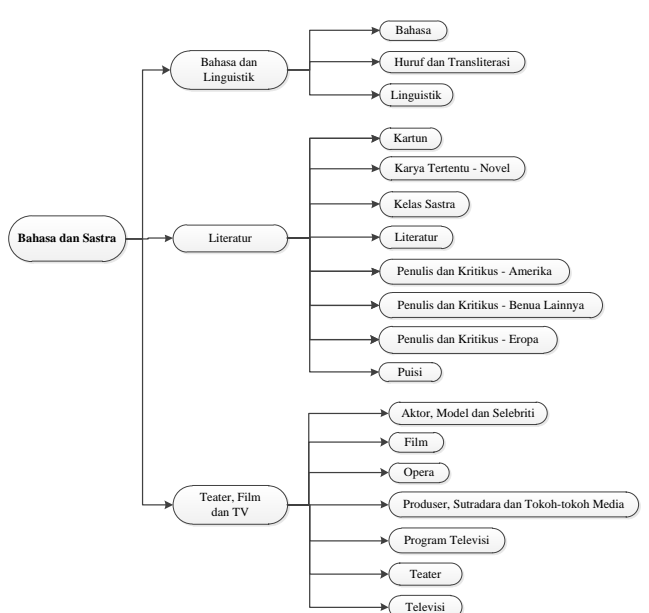

Gambar 2 : rancangan class "Bahasa dan Sastra"

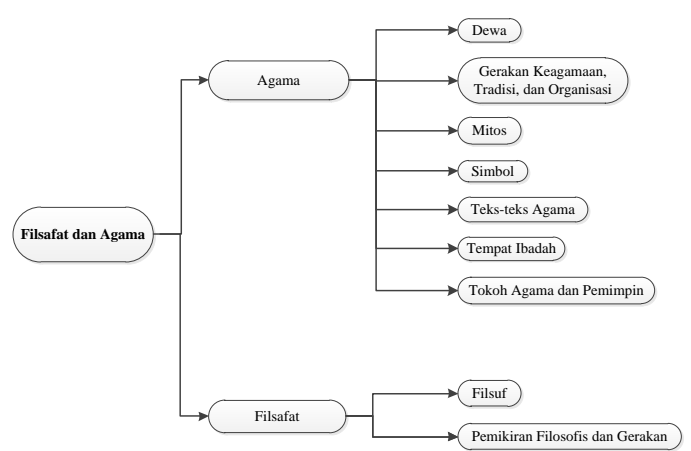

Gambar 3 : rancangan class "Filsafat dan Agama"

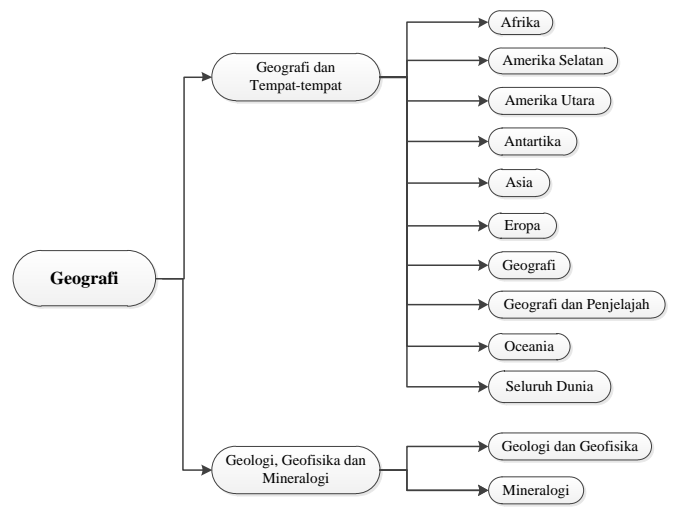

Gambar 4 : rancangan class "Geografi"

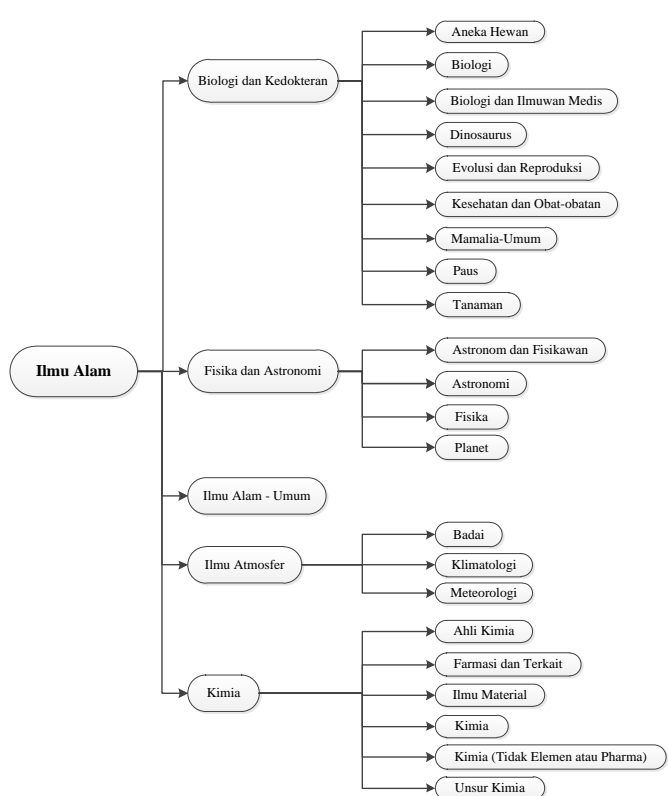

Gambar 5 : rancangan class "Ilmu Alam"

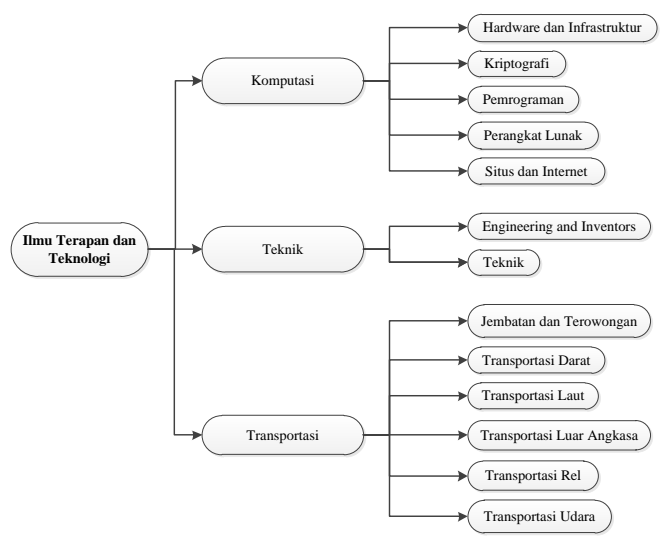

Gambar 6 : rancangan class "Ilmu Terapan dan Teknologi"'

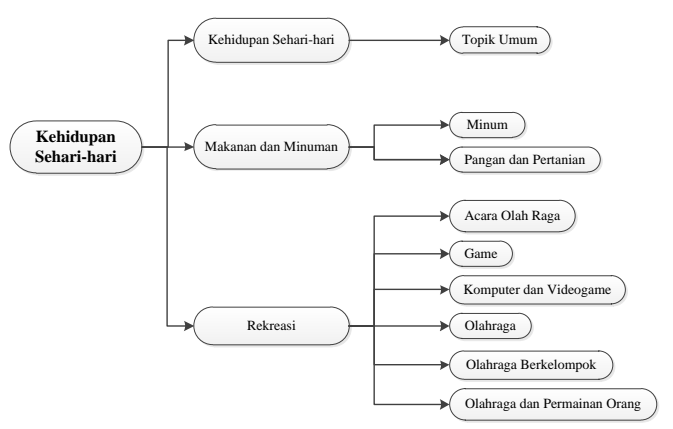

Gambar 7 : rancangan class "Kehidupan Seharihari" 


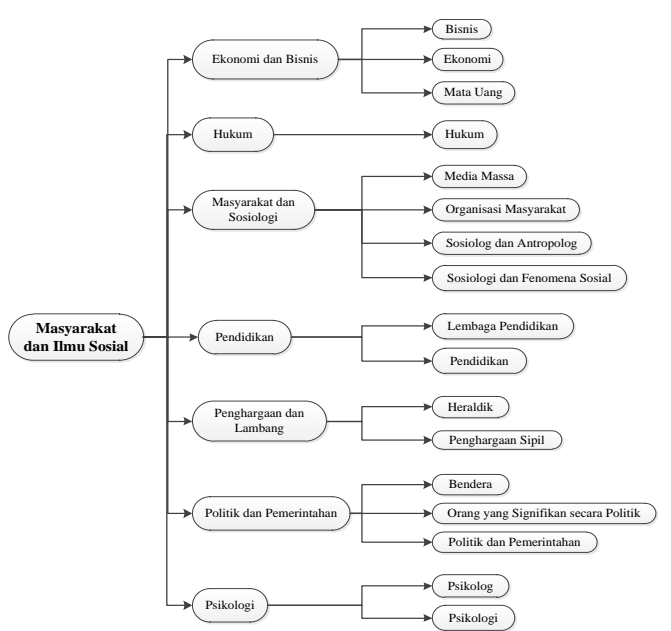

Gambar 8 : rancangan class "Masyarakat dan Ilmu Sosial"

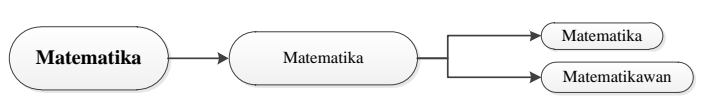

Gambar 9 : rancangan class "Matematika"

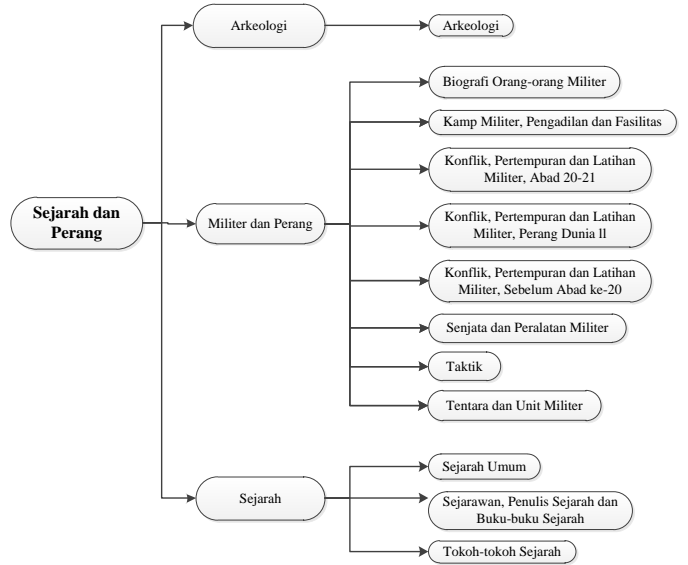

Gambar 10 : rancangan class "Sejarah dan Perang"

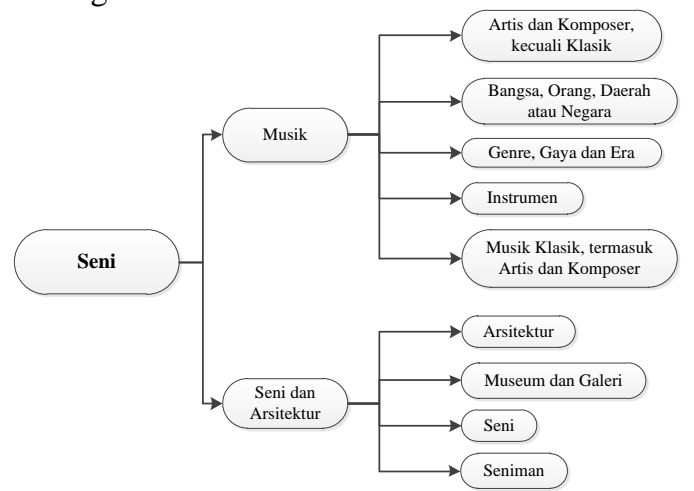

Gambar 11 : rancangan class "Seni”"

5. Mendefinisikan slot atau properties pada class

Ada dua tipe property, yaitu Object Propertiesberfungsi untuk menghubungkan instances antar class dan Data Properties yangberfungsi untuk menghubungkan instances dengan values dari property tiap instances. Pada Object Properties, didefinisakan dua propertyyaitu hasMember dan isMemberOf. Sedangkan Data Properties didefinisikan tiga property, yaitu Isi, Judul dan Nama.

6. Mendefinisikan facets pada slots

Mendefinisikan batasan (facet) property atau slot dengan mengisi Nama Property, Range, Type dan Keterangan pada setiap class.

Tabel 1: Rancangan Slot Pada Class "Kat_Bahasa_dan_Sastra"

\begin{tabular}{|c|c|c|c|}
\hline Property & Range & Type & Keterangan \\
\hline Nama & $\begin{array}{l}\text { Single } \\
\text { String }\end{array}$ & $\begin{array}{l}\text { Data } \\
\text { Property }\end{array}$ & Nama Class \\
\hline hasMember & $\begin{array}{l}\text { Multiple } \\
\text { Subclass }\end{array}$ & $\begin{array}{l}\text { Object } \\
\text { Property }\end{array}$ & $\begin{array}{l}\text { Menghubungkan class } \\
\text { Kat_Bahasa_dan_Sast } \\
\text { ra dengan class } \\
\text { Sub1_Bahasa_dan_Li } \\
\text { nguistik, } \\
\text { Sub1_Literatur, } \\
\text { Sub1_Teater_Film_da } \\
\text { n_TV }\end{array}$ \\
\hline
\end{tabular}

7. Membuat instances

Langkah pendefinisian sebuah instanceclass dimulai dengan memilih class, membuat individu instance dari class kemudian yang terakhir mengisi property dari individu instanceclass. Sebagai contoh, instance "Bahasa Indonesia" menerangkan secara khusus anggota dari class "Bahasa".

Tabel 2 : Rancangan Instance "Bahasa Indonesia" Dari Class "Bahasa"

\begin{tabular}{|c|c|}
\hline $\begin{array}{l}\text { Propert } \\
\mathbf{y}\end{array}$ & Value \\
\hline Judul & Bahasa Indonesia \\
\hline Isi & $\begin{array}{l}\text { res/Wikipedia/Bahasa dan Sastra/Bahasa } \\
\text { dan Linguistik/Bahasa/Bahasa } \\
\text { Indonesia.xml }\end{array}$ \\
\hline isMemberOf & Sub2_Bahasa \\
\hline
\end{tabular}

\section{Implementasi Ontologi}

Implementasi class dan struktur hirarkinya pada aplikasi ini dimulai dengan menciptakan class-class dan sub class yang telah ditentukan. Class-class pada ontologi aplikasi ini terdiri dari sepuluh class induk (super class), yaitu class "Bahasa dan Sastra", class "Filsafat dan Agama", class "Geografi", class "Ilmu Alam", class "Ilmu Terapan dan Teknologi", class "Kehidupan Seharihari", class "Masyarakat dan Ilmu Sosial", class "Matematika", class "Sejarah dan Perang" dan class "Seni". 


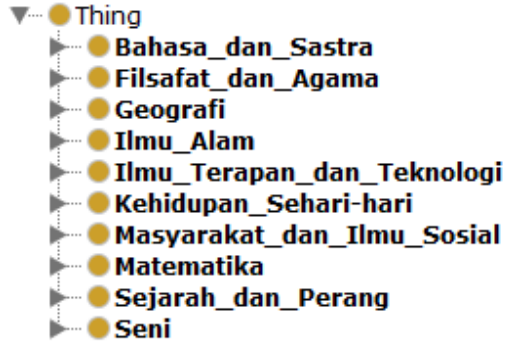

Gambar 12 : Implementasi Struktur dan Hirarki Class Induk (Superclass)

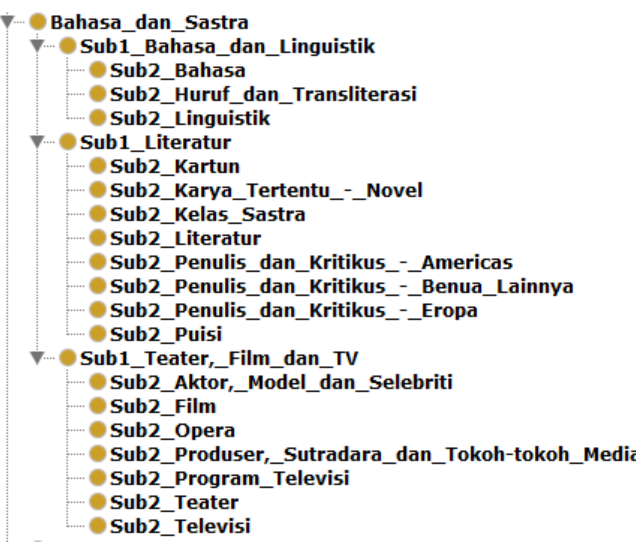

Gambar 13 : Implementasi Struktur dan Hirarki Class "Bahasa dan Sastra"

\section{Implementasi Property}

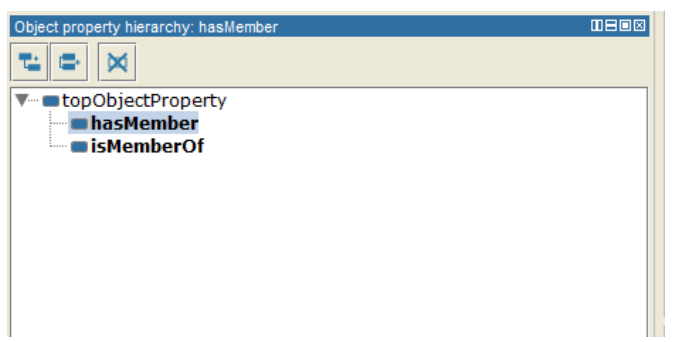

Gambar 14 : Pendefinisian Nama Object Property

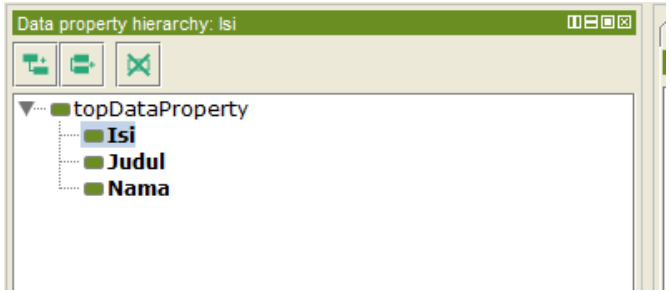

Gambar 15 : Pendefinisian Nama Data Property

\section{Implementasi Instances}

Pembuatan instances yaitu membuat individual baru dan melakukan pengisian property dengan nilai (values) pada individual tersebut. Setiap instances yang terbentuk akan mewakili class yang telah dibuat dan setiap artikel. Pembuatan instancesclass dimulai dengan pemberian nama instances, memilih Types (class) dan pengisian property.

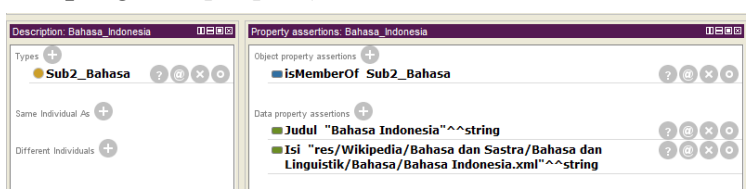

Gambar 16 : Instances "Bahasa_Indonesia"

\section{Pengujian}

1. Pengujian Fungsional Sistem

Untuk menguji kinerja aplikasi dibutuhkan pengujian fungsionalitas sistem. Pengujian ini dilakukan dengan cara menjalankan setiap fitur dalam aplikasi dan melihat apakah hasilnya sudah sesuai dengan yang diharapkan.

Tabel 3 : Pengujian Sistem

\begin{tabular}{|c|c|c|c|}
\hline Pengujian & $\begin{array}{l}\text { Data } \\
\text { Masukkan }\end{array}$ & $\begin{array}{l}\text { Hasil yang } \\
\text { diharapkan }\end{array}$ & Hasil \\
\hline \multirow{4}{*}{$\begin{array}{l}\text { Pencarian } \\
\text { berdasarkan } \\
\text { kata kunci }\end{array}$} & $\begin{array}{l}\text { Kata kunci } \\
\text { "Bahasa } \\
\text { Indonesia" }\end{array}$ & $\begin{array}{l}\text { Menampilkan } \\
\text { judul dan isi } \\
\text { artikel dari kata } \\
\text { kunci beserta } \\
\text { artikel terkait } \\
\text { dan kategori } \\
\text { terkait }\end{array}$ & \multirow{4}{*}{ Berhasil } \\
\hline & $\begin{array}{l}\text { Kata kunci } \\
\text { "Indonesia } \\
\text { Bahasa" }\end{array}$ & $\begin{array}{l}\text { Menampilkan } \\
\text { beberapa } \\
\text { kemungkinan } \\
\text { tautan dari kata } \\
\text { kunci } \\
\text { "Indonesia } \\
\text { Bahasa" }\end{array}$ & \\
\hline & $\begin{array}{l}\text { Kata kunci } \\
\text { "Bahasa" }\end{array}$ & $\begin{array}{l}\text { Menampilkan } \\
\text { beberapa } \\
\text { kemungkinan } \\
\text { tautan dari kata } \\
\text { kunci "Bahasa" }\end{array}$ & \\
\hline & $\begin{array}{l}\text { Kata kunci } \\
\text { "presiden" yang } \\
\text { tidak terdapat } \\
\text { pada ontologi } \\
\text { wiki }\end{array}$ & $\begin{array}{l}\text { Menampilkan } \\
\text { pesan bahwa } \\
\text { kata kunci tidak } \\
\text { ditemukan }\end{array}$ & \\
\hline $\begin{array}{l}\text { Pencarian } \\
\text { berdasarkan } \\
\text { tautan pada } \\
\text { artikel } \\
\text { terkait }\end{array}$ & $\begin{array}{l}\text { Tautan "Bahasa } \\
\text { Aceh" }\end{array}$ & $\begin{array}{l}\text { Menampilkan } \\
\text { judul dan isi } \\
\text { artikel } \\
\text { "Bahasa Aceh" } \\
\text { beserta artikel } \\
\text { terkait }\end{array}$ & Berhasil \\
\hline $\begin{array}{l}\text { Pencarian } \\
\text { berdasarkan } \\
\text { tautan pada } \\
\text { kategori } \\
\text { terkait }\end{array}$ & $\begin{array}{l}\text { Tautan } \\
\text { "Huruf dan } \\
\text { Transliterasi" }\end{array}$ & $\begin{array}{l}\text { Menampilkan } \\
\text { tautan artikel } \\
\text { dalam kategori } \\
\text { "Huruf dan } \\
\text { Transliterasi" }\end{array}$ & Berhasil \\
\hline $\begin{array}{l}\text { Pencarian } \\
\text { berdasarkan } \\
\text { tautan pada } \\
\text { kategori } \\
\text { utama } \\
\text { artikel }\end{array}$ & $\begin{array}{l}\text { Tautan } \\
\text { "Bahasa dan } \\
\text { Sastra" }\end{array}$ & $\begin{array}{l}\text { Menampilkan } \\
\text { tautan sub } \\
\text { kategori dalam } \\
\text { kategori } \\
\text { "Bahasa dan } \\
\text { Sastra" }\end{array}$ & Berhasil \\
\hline
\end{tabular}

2. Pengujian Akurasi Sistem

Pengujian akurasi sistem bertujuan untuk menghitung tingkat kerelevanan hasil pencarian oleh sistem dengan kata kunci yang dimasukkan 
oleh pengguna (query). Dalam pengujian ini terdapat 2 nilai yang diukur, yaitu :

1. Jumlah artikel sebenarnya (N1), yaitu didapat dari perhitungan jumlah artikel yang sesuai atau terkait dari keseluruhan artikel dengan kata kunci yang diujikan berdasar pengetahuan penguji.

2. Jumlah artikel oleh sistem (N2), yaitu didapat dari perhitungan jumlah artikel yang ditampilkan sistem.

Pada pengujian ini juga digunakan tiga perhitungan untuk mengukur akurasi sistem yang menerapkan metode semantic web, yaitu :

1. Precision,merupakan tingkat ketepatan antara informasi yang diminta oleh pengguna dengan jawaban yang diberikan oleh sistem. Nilai Precision tertinggi adalah 1, yang berarti seluruh dokumen yang ditemukan adalah relevan. Pada pengujian ini, Precision dirumuskan sebagai berikut.

$$
\text { Precision }=\frac{N 2 \cap N 1}{N 2}
$$

2. Recall, merupakan tingkat keberhasilan sistem dalam menemukan kembali sebuah informasi. Nilai Recall tertinggi adalah 1, yang berarti seluruh dokumen dalam koleksi berhasil ditemukan. Pada pengujian ini, Recall dirumuskan sebagai berikut.

$$
\text { Recall }=\frac{N 2 \cap N 1}{N 1}
$$

3. F-Score, merupakan gabungan dari Precision dan Recall. Pada pengujian ini, FScore dirumuskan sebagai berikut.

$$
\text { F-Score }=\frac{2 \times(\text { Precision } \times \text { Recall })}{(\text { Precision }+ \text { Recall })}
$$

Tabel 4 : Data Hasil Pengujian Akurasi Sistem

\begin{tabular}{|c|l|c|c|c|c|}
\hline No & \multicolumn{1}{|c|}{ Query } & N1 & N2 & $\begin{array}{c}\text { Preci- } \\
\text { sion }\end{array}$ & Recall \\
\hline 1 & Bahasa Indonesia & 9 & 3 & 1 & 0.333 \\
\hline 2 & Mitologi & 6 & 3 & 1 & 0.5 \\
\hline 3 & Amerika Serikat & 6 & 3 & 1 & 0.375 \\
\hline 4 & Hukum Fisika & 5 & 3 & 1 & 0.6 \\
\hline 5 & Pesawat Terbang & 4 & 3 & 1 & 0.75 \\
\hline 6 & Bola Basket & 4 & 3 & 1 & 0.75 \\
\hline 7 & $\begin{array}{l}\text { Daftar Sosiolog } \\
\text { Indonesia }\end{array}$ & 8 & 3 & 1 & 0.375 \\
\hline 8 & Matematika & 4 & 3 & 1 & 0.75 \\
\hline 9 & Soekarno & 6 & 3 & 1 & 0.5 \\
\hline 10 & $\begin{array}{l}\text { Galeri Nasional } \\
\text { Indonesia }\end{array}$ & 8 & 3 & 1 & 0.375 \\
\hline \multicolumn{2}{|c|}{ Rata-rata } & & 1 & 0.53083 \\
\hline \multicolumn{4}{|c|}{ Fcore } & & 0.693522047 \\
\hline
\end{tabular}

Berdasarkan pengujian fungsional sistem yang telah dilakukan, diketahui bahwa sistem pada penelitian ini telah berjalan dengan baik secara fungsional dan menghasilkan output yang diharapkan.

Pada perhitungan N1, didapatkan nilai jumlah artikel yang berhubungan atau relevan dengan query uji berdasarkan pengetahuan penguji. Pada perhitungan N2, didapatkan nilai jumlah artikel yang ditampilkan oleh sistem berdasarkan query uji. Dari data N1 dan N2, kemudian digunakan untuk menghitung akurasi sistem melalui tiga perhitungan, yaitu Precision, Recall dan F-Score.

Berdasarkan perhitungan Precision, didapatkan nilai 1 atau nilai tertinggi untuk seluruh query uji, yang berarti seluruh dokumen yang ditampilkan oleh sistem adalah relevan. Sedangkan pada perhitungan Recall, diperoleh nilai rata-rata 0.51 .

Pada perhitungan akhir akurasi sistem, pada perhitungan $F$-Score diperoleh nilai persentase $69,35 \%$, yang berarti bahwa sistem mampu menampilkan artikel dengan cukup relevan.

\section{Kesimpulan dan Saran}

Berdasarkan pembahasan pada makalah ini mengenai penerapan teknologi semantic web pada artikel Wikipedia Indonesia maka dapat ditarik beberapa kesimpulan sebagai berikut :

1. Ontologi pada aplikasi Semantic Wikipedia Indonesia dimodelkan berdasarkan class-class dari hasil clustering artikel Wikipedia Indonesia serta dilengkapi dengan pendefinisian property-property dari masingmasing class.

2. Pencarian pada aplikasi Semantic Wikipedia Indonesia ini mampu menampilkan artikel terkait dan kategori terkait yang relevan dengan artikel hasil pencarian.

Aplikasi Semantic Wikipedia Indonesia ini dapat dikembangkan dengan menambah jumlah artikel Wikipedia Indonesia yang digunakan agar sistem mampu menampilkan lebih banyak artikel terkait.

\section{Daftar Pustaka:}

Antoniou, Grigoris and van Harmelen, Frank. 2008. "A Semantic Web Primer, Second Edition". Massachusetts Institute of Technology

Gunawan dan Halim, Fandi. 2014. "Penerapan Web Semantik Untuk Aplikasi Pencarian Pada Repositori Koleksi Penelitian, Studi Kasus: Program Studi Sistem Informasi Stmik Mikroskil Medan". Skripsi. Medan : STMIK Mikroskil

https://en.wikipedia.org/wiki/Wikipedia [11 Desember 2015]

https://id.wikipedia.org/wiki/Istimewa:Statis tik [11 Desember 2015]

Lassila, Ora and Swick, Ralph R. 1999. Resource Description Framework (RDF)

Model and Syntax Spesification. [Online] Tersedia 
http://www.w3.org/TR/1999/REC-RDF-

syntax-19990222/. [16 Maret 2016]

Noy. N. F. dan McGuinnes. D. L. 2000. Ontology

Development 101: A Guide to

Creating Your First, Stanford University, Stanford. [Online] Tersedia http://protege.stanford.edu/publications/onto logy_development/ontology101-noymcguinness.html [9 Maret 2016]

Nugroho, Atmoko. 2012. "Membangun Ontologi Jurnal Menggunakan Protégé". JURNAL TRANSFORMATIKA, Volume 10, No.1, Juli 2012 : 20 - 25. Fakultas Teknologi Informasi dan Komunikasi Universitas Semarang

Rahman, Muhammad Arief. 2015. "Penerapan Teknologi Semantic Web Pada Ensiklopedia Alam". Skripsi. Malang : Politeknik Negeri Malang

Rahutomo, F. dan Sarno, R. (2008), "Semantic Search Wikipedia by applying Agent Matcher Architecture", ProceedingsInternational Conference on Information \& Communication Technology and System, FTIF Institut Teknologi Sepuluh Nopember, Surabaya, hal. 646-653.

Seaborne, A. dan Prud'hommeaux, E. 2008. SPARQL Query Language for RDF, [Online] Tersedia: https://www.w3.org/TR/RDF-sparql-query [16 Maret 2016]

Tanaamah, Andeka Rocky dan Wellem, Theophilus. 2009. "Semantik Web sebagai Solusi Pemecahan Masalah Promosi Kepariwisataan di Indonesia”. Jurnal Teknologi Informasi - Aiti, Vol.6. No. 2, Agustus 2009:101-200. Fakultas Teknologi Informasi Universitas Kristen Satya Wacana

Zebua, Javier dan Mustikasari, Metty, S.Kom., MSC. "Aplikasi Pencarian Buku Berbasis Web Semantik Untuk Perpustakaan Smk Yadika 7 Bogor". Skripsi. Jakarta : Universitas Gunadarma. 